\title{
PENGARUH PEMBELAJARAN RECIPROCAL TEACHING DIPADUKAN THINK PAIR SHARE TERHADAP PENINGKATAN KEMAMPUAN METAKOGNITIF BELAJAR BIOLOGI SISWA SMA BERKEMAMPUAN AKADEMIK BERBEDA DI KABUPATEN SIDOARJO
}

\author{
Nur Efendi \\ Universitas Muhammadiyah Sidoarjo \\ J1. Mojopahit 666B Sidoarjo Telp (031) 8945444 Kode Pos 61215, e-mail: \\ nurefendi17@ymail.com
}

\begin{abstract}
In the globalization era, the world is developed without the boundary, the development of the sciences and technologies have been needed by people in the nation, to increase the quality of education. In the biology (sciences) has been needed to adapt student-centered learning paradigm than the teacher-centered. The purposes of the study are to apply the Reciprocal Teaching (RT), Think Pair Share (TPS), Reciprocal Teaching Plus Think Pair Share (RT+TPS) learning strategic to increase the metacognitive ability in learning biology for the senior high school students in Sidoarjo with different academic capability. The study is a quasi experiment. The research design is pre-post test non-equivalent control group design with the $4 \times 2$ factorial pattern. The total sample is 240 students. Data are subjected to the ANACOVA statistic and followed by the LSD test with 0.05 significance degree. The result of inferential analysis indicates that the learning strategy and academic capability influenced the metacognitive ability students. The average score metacognitive ability remarks in the RT+TPS with remarks 77.73 and the higher $1.65 \%$ than TPS with remarks 76.44 , but the really different and the higher $2.92 \%$ than $R T$ with remarks $75.45,4.33 \%$ than the Conventional with remarks 74.36 . The average score met cognitive ability remarks Up students academic capability performs is 76.53 is the really different and the higher $1.39 \%$ than the Down student academic capability performs is 75.46. The average score RT+TPS strategy learning in the Up academic capability with the remarks 78.93 and the higher $1.42 \%$ than TPS-Up academic with remarks 77.82, but the really different and the higher $4.86 \%$ than RT-Up academic with remarks 75.10, 5,91\% than the Conventional-Up academic with remarks 74.27. The average score metacognitive ability strategy learning RT+TPS-Up academic is really different and higher $3.05 \%$ than $R T+T P S$ Down academic with remarks 76.53. The RT+TPS strategy learning application have the best result to increase the metacognitive ability in learning biology if it is compared with the RT, TPS, or Conventional strategy learning on the Up or Down students academic capability performs. This strategy can be used for the largest biology learning and as the alternative to manage the instruction learning in the class, the factor fundamental to make decision for the stake holders, and the first research for the references continuous research.
\end{abstract}


Keywords: Reciprocal Teaching Plus Think Pair Share (RT+TPS), the metacognitive ability biology study students.

\section{PENDAHULUAN}

Pada era globalisasi, dengan ciriciri: dunia tanpa batas, kemajuan ilmu pengetahuan dan teknologi, kesadaran terhadap hak dan kewajiban asasi manusia, kerjasama dan kompetisi antar bangsa menuntut setiap manusia pada suatu bangsa untuk meningkatkan kualitas pendidikan (Tilaar, 2002). Biologi merupakan bagian dari sains yang memiliki dua dimensi yang bersifat mendasar, yakni dimensi proses dan produk. Biologi sebagai dimensi proses mengandung keterampilan, nilai, dan sikap yang harus dimiliki seseorang atau siswa untuk mendapatkan dan mengembangkan pengetahuan biologi, dimensi proses ini sangat terkait dengan kemampuan metakognisi siswa. Biologi sebagai dimensi produk merupakan wujud dari hasil belajar siswa, meliputi: sumber fakta, sumber teori, sumber prinsip, dan sumber konsep.

Pada Kurikulum Tingkat Satuan Pendidikan (KTSP), tujuan pembelajaran biologi Sekolah Menengah Atas (SMA) adalah:

(1) mengembangkan daya penalaran untuk memecahkan masalah yang dihadapi dalam kehidupan sehari-hari, mengembangkan keterampilan proses untuk memperoleh konsep-konsep biologi dan menumbuhkan nilai dan sikap ilmiah, (3) menerapkan konsep dan prinsip biologi untuk menghasilkan karya yang berkaitan dengan kebutuhan manusia (Depdiknas, 2004: 5). Adapun materi pembelajaran biologi kelas $\mathrm{X}$ semester II, yang terdiri dari pokok bahasan: 1) keanekaragaman hayati (biodiversitas), 2) dunia tumbuhan (kingdom plantae), 3) dunia hewan (kingdom animalia), 4) ekosistem, dan 5) pencemaran dan perubahan lingkungan, maka sangat diperlukan adanya strategi pembelajaran yang dapat mengembangkan dimensi proses dan produk sesuai dengan apa yang ditetapkan pada kurikulum melalui keterlibatan siswa langsung dalam 
kegiatan pembelajaran, seperti: melakukan observasi, mendemonstrasikan langkah-langkah, berdiskusi secara kelompok, mempresentasikan hasil kerja kelompok dan menghasilkan karya.

Menurut Wilson (2001), paradigma pendidikan berbasis kompetensi mencakup kurikulum, pedagogi, dan penilaian yang menekankan pada standar atau hasil. Kurikulum berisi bahan ajar yang diberikan kepada peserta didik melalui proses pembelajaran. Proses pembelajaran dilaksanakan dengan menggunakan pedagogi yang mencakup strategi atau metode mengajar. Tingkat keberhasilan belajar yang dicapai siswa dapat dilihat pada hasil belajar, yang mencakup ujian, tugas-tugas, dan pengamatan sebagai dimensi produk. Dengan demikian, keberhasilan pembelajaran biologi tidak hanya ditentukan oleh siswa saja, tetapi peran serta guru dalam mengelola pembelajaran juga sangat menentukan. Oleh sebab itu, upaya peningkatan mutu pembelajaran guruguru biologi SMA sangat diperlukan guna ketercapaian hasil belajar yang ditetapkan.
Kabupaten Sidoarjo merupakan daerah dengan penduduk yang padat, membutuhkan tingkat kompetensi peserta didik yang tinggi. Jumlah SMA Negeri dan Swasta di Sidoarjo adalah 35 sekolah. Hasil survei awal bulan Juni-Agustus 2010 dan Mei-Juli 2011 menunjukkan bahwa pembelajaran yang dilakukan oleh guru di kelas sebagian besar masih berpusat pada guru (teacher-centered) $63,64 \%$, sedangkan pembelajaran yang berpusat pada siswa (studentcentered) $36,36 \%$. Hasil survei terkait dengan strategi pembelajaran Reciprocal Teaching menunjukkan bahwa $17,65 \%$ guru mengenal strategi ini dan $82,35 \%$ belum mengenal, sedangkan untuk strategi pembelajaran Think Pair Share $36,37 \%$ guru mengenal dan $63,63 \%$ guru belum mengenal (Efendi, 2011).

Berdasarkan hasil survei ini menunjukkan bahwa kualitas guru dalam mengelola pembelajaran masih rendah dan perlu ditingkatkan untuk mencapai ketuntasan hasil belajar yang ditetapkan dan kompetensi yang lainnya. Guru hanya sekedar memberikan informasi kepada siswa, tanpa melibatkan siswa dalam proses untuk mendapatkan informasi tersebut. 
Adapun kriteria ketuntasan hasil belajar yang ditetapkan pada kurikulum KTSP adalah individual $P \geq 0,75$ dan klasikal $P \geq 0,85$, artinya siswa yang memperoleh nilai 75 dalam satu kelas sebanyak $85 \%$ (Hutabarat, 2005; Wulandari dan Muchlis, 2011).

Selain keadaan di atas, kemampuan guru dalam memberdayakan kemampuan metakognitif yang dimiliki oleh siswa masih kurang, hasil survei menunjukkan bahwa terdapat $11,37 \%$ guru yang pernah mengembangkan keterampilan metakognisi, sedangkan $88,63 \%$ belum pernah. Sebagian besar guru yang belum menerapkan keterampilan metakognisi karena belum memahami langkah-langkah dalam memberdayakan keterampilan metakognisi dan belum menyadari bahwa keterampilan metakognisi dapat memengaruhi proses dan hasil belajar siswa.

$$
\text { Perlu adanya penerapan }
$$

pembelajaran yang mengacu pada pendekatan konstruktivis untuk diperkenalkan pada guru, yang menekankan pada proses pembelajaran bagaimana untuk belajar (learning how to learn), sehingga konsep maupun prinsip biologi menjadi bermakna. Pembelajaran seperti ini, sejalan dengan empat visi pendidikan menuju abad ke-21 versi UNESCO, yaitu: 1) learning to think (belajar berpikir), 2) learning to do (belajar berbuat/hidup), 3) learning to live together (belajar hidup bersama), 4) learning to be (belajar menjadi diri sendiri) (Sidi, 2001). Untuk mencapai ketuntasan pembelajaran biologi ini sikap kemandirian peserta didik sangat diperlukan. Cerminan peserta didik yang mandiri adalah independent learner, strategic learner, dan selfregulated learner.

Cerminan ketiga sikap peserta didik mandiri tersebut dapat dikembangkan melalui pendekatan pengajaran dua arah (reciprocal teaching). Menurut Palinscar dan Brown (1984), pengajaran dua arah (reciprocal teaching) merupakan suatu pendekatan pembelajaran yang melatihkan keterampilan metakognisi melalui empat strategi, yaitu: 1) menyusun pertanyaan-pertanyaan dari teks bacaan dan jawabannya, 2) membuat rangkuman (ringkasan) informasi-informasi penting dari teks bacaan, 3) membuat prediksi, dan 4) mengidentifikasi hal-hal yang kurang 
jelas dan memberikan klarifikasi (penjelasan).

Ibrahim (2008) menyatakan bahwa 1) keterampilan yang dilatihkan dan bentuk aktivitas yang dilakukan oleh siswa selama kegiatan belajar, dalam reciprocal teaching berdampak positif terhadap kemampuan komunikasi siswa, karena selama pembelajaran siswa mengajukan pertanyaan, mengomentari jawaban teman yang lain, 2) menurut Keller (1987) yang dialihbahasakan oleh Kardi (2002), pada teori motivasi ARCS (Attention, Relevance, Confidence, Satisfaction), siswa akan termotivasi jika apa yang dipelajarinya menarik perhatiannya, relevan dengan kebutuhan siswa, apa yang mereka pelajari menyebabkan mereka puas, dan menambah percaya dirinya. Dalam pembelajaran reciprocal teaching, siswa aktif mencari tahu informasi yang diperlukan untuk menjawab pertanyaannya sendiri sehingga relevan dengan kebutuhan mereka sendiri, 3) selama kegiatan belajar mengajar siswa membuat rangkuman, jadi dilatih untuk menemukan ide pokok di dalam bahan bacaan dan ini merupakan keterampilan penting untuk belajar.
Semua uraian tersebut ternyata sejalan dengan hasil penelitian yang menerapkan reciprocal teaching ini, telah berhasil meningkatkan prestasi belajar yang rendah (Palincsar dan Brown, 1984; Palinscar dalam Slavin 1994). Kelemahan pada pengajaran dua arah (reciprocal teaching) ini adalah kejenuhan siswa yang dihadapkan pada pemahaman text books saja (terutama pada siswa yang pasif) dan tidak semua siswa mendapat bagian untuk menjadi "guru siswa", padahal banyak siswa yang aktif ingin terlibat dalam dialog terutama ingin menjadi "guru siswa" (Khabibah, 1999; Efendi, 2005).

Mereduksi kelemahan yang ada, pembelajaran reciprocal teaching ini dapat diciptakan suasana pembelajaran yang lebih menekankan arti kebersamaan, seperti think pair share. Sesuai dengan namanya think pair share, maka sintaks strategi ini adalah: 1) diawali dengan "thinking" dengan cara guru mengajukan pertanyaan atau isu terkait dengan pelajaran untuk dipikirkan oleh peserta didik, 2) "pairing", guru meminta siswa berpasang-pasangan untuk berdiskusi, 3) “sharing”, hasil diskusi antar-siswa di tiap-tiap pasangan 
dibicarakan dengan pasangan seluruh kelas (Suprijono, 2009).

Perpaduan antara strategi pembelajaran reciprocal teaching dengan think pair share merupakan suatu alternatif strategi pembelajaran yang dapat dilakukan untuk menciptakan pembelajaran yang menyenangkan dan bermakna bagi siswa, sehingga informasi yang disampaikan oleh guru dapat menjadi hasil pengetahuan yang diperoleh siswa secara mendalam.

Berdasarkan uraian di atas, dilakukan penelitian dengan judul "Pengaruh Pembelajaran Reciprocal Teaching Dipadukan Think Pair Share terhadap Peningkatan Kemampuan Metakognitif Belajar Biologi Siswa SMA Berkemampuan Akademik Berbeda di Kabupaten Sidoarjo", dengan rumusan permasalahan penelitian sebagai berikut.

1. Apakah ada pengaruh strategi pembelajaran terhadap peningkatan kemampuan metakognitif belajar biologi siswa SMA di Kabupaten Sidoarjo?

2. Apakah ada pengaruh kemampuan akademik terhadap kemampuan metakognitif belajar biologi siswa SMA di Kabupaten Sidoarjo?
3. Apakah ada pengaruh interaksi strategi pembelajaran dan kemampuan akademik terhadap kemampuan metakognitif biologi siswa SMA di Kabupaten Sidoarjo?

\section{METODE PENELITIAN}

\section{Rancangan dan Prosedur Penelitian}

Penelitian ini merupakan penelitian eksperimen semu atau quasi eksperimen yang dilakukan dengan menggunakan rancangan faktorial (4x2) The Non-Equivalent ControlGroup Design (Pretest-PosttestControl Group Design) (Sugiyono, 2006). Adapun variabel penelitian iniadalah: 1) variabel bebas: strategi pembelajaranreciprocal teaching,think pair share, reciprocal teaching dipadukan think pair share, dan konvensional (sebagai kontrol), 2) variabel moderator: kemampuan akademik atas dan bawah, 3) variabel terikat: kemampuan metakognitifdan hasil belajar biologi siswa.

\section{Populasi dan Sampel}

\section{Populasi}

Populasi yang digunakan pada penelitian ini adalah Siswa SMA kelas $\mathrm{X}$ semester II tahun pelajaran 2011/2012pada 13 SMA Negeri (SMAN 1 Tarik, SMAN 1 Krian, 
SMAN 1 Wonoayu, SMAN 1 Taman,

SMAN 1 Waru, SMAN 1 Gedangan,

SMAN 1 Sidoarjo, SMAN 2 Sidoarjo, SMAN 3 Sidoarjo, SMAN 4 Sidoarjo, SMANOR Sidoarjo, SMAN 1 Krembung, SMAN 1 Porong) di Kabupaten Sidoarjo.

\section{Sampel}

Sampel penelitian adalah sejumlah individu dari populasi yang dijadikan sampel penelitian dengan menggunakan teknik multiple stage sampling yaitu pengambilan sampel secara bertahap, dengan rincian: a) penentuan sekolah berkemampuan akademik atas dan bawah dilakukan dengan teknik stratified sampling, dengan memperhatikan nilai hasil Ujian Nasional (UN) SMP tahun pelajaran 2010/2011 yang digunakan sebagai dasar penerimaan untuk masuk ke SMA, b) penentuan kelas eksperimen dilakukan dengan teknik random sampling yaitu pengambilan sampel secara acak, sebagai sampel siswa berkemampuan akademik atas (AA) dan berkemampuan akademik bawah (AB) pada sekolah yang ditentukan. Jumlah total sampel siswa adalah 240 siswa, terdiri dari: 1) sampel untuk siswa berkemampuan akademik atas (AA) adalah 120 siswa (strategi $R T=30$ siswa, $T P S=30$ siswa, $\quad R T+T P S=30$ siswa, Konvensional= 30 siswa) dan 2) siswa berkemampuan akademik bawah (AB) dengan jumlah 120 siswa (strategi $R T=30$ siswa, $T P S=30$ siswa, $R T+T P S=30$ siswa, Konvensional= 30 siswa).

\section{Waktu dan Pelaksanaan Penelitian}

Pelaksanaan penelitian pada bulan Juli-Agustus 2010 dan JanuariMei 2012 semester genap tahun pelajaran 2011/2012 di SMA Negeri Kabupaten Sidoarjo.

\section{Instrumen Penelitian}

Instrumen Tes

Instrumen tes yang digunakan berupa essay test yang bertujuan untuk mengukur pemahaman konsep. Aspek kognitif yang diukur adalah dimensi proses dari ranah kognitif menurut Anderson, dkk (2001) dibedakan menjadi: mengingat $(\mathrm{C} 1)$, memahami (C2), menerapkan (C3), menganalisis (C4), mengevaluasi (C5), dan mencipta (C6). Sebelum instrumen soal digunakan, maka terlebih dahulu dilakukan uji validasi, reliabilitas, uji 
tingkat kesukaran soal, dan uji daya beda soal.

\section{Rubrik Penskoran}

Rubrik hasil belajar siswa yang mengacu pada pemahaman konsep sebagai hasil belajar ranah kognif, diadaptasi dari Hart (1994) terdiri dari skor penilaian dari interval $0-4$, yang diperoleh siswa melalui tes: $\mathrm{C} 1$ (ingatan), C2 (pemahaman), C3 (penerapan), $\mathrm{C} 4 \quad$ (analisis), $\mathrm{C} 5$ (evaluasi), dan C6 (mencipta).

Uji Validasi, Reliabilitas, Tingkat Kesukaran dan Daya Pembeda Instrumen Tes

\section{Pengujian Validitas Instrumen Tes}

Uji validitas instrumen hasil belajar kognitif bertujuan untuk mengetahui tingkat kesesuaian soal agar dapat mengukur apa yang seharusnya diukur. Uji validitas menyangkut validitas konstruksi, validitas isi, dan validitas kriteria dilakukan oleh para ahli (pembimbing). Uji lapangan yang merupakan validitas empirik sebagai uji validitas butir (Sugiyono, 2007). Validitas butir tes dihitung dengan koefisien korelasi skor setiap butir soal dengan skor total dengan menggunakan Korelasi Product Moment Pearson (Sugiyono, 2007).

\section{Uji Reliabilitas Instrumen Tes}

Reliabilitas menunjukkan pada tingkat keterandalan sesuatu yang dapat dipercaya dan dapat diandalkan (Arikunto, 2006). Untuk menguji reliabilitas instrumen dalam penelitian ini digunakan rumus Alpha Cronbach (Sugiyono, 2007:184). Penghitungan dilakukan dengan menggunakan program SPSS 16 for Windows.

\section{Uji Tingkat Kesukaran Soal}

Uji tingkat kesukaran ini bertujuan untuk memperoleh soal yang baik, dimana soal yang baik adalah soal yang tidak terlalu mudah atau tidak terlalu sukar. Bilangan yang menunjukkan sukar dan mudahnya suatu soal disebut indeks kesukaran dan dilambangkan dengan $P$ (difficulty index). Adapun pengklasifikasian kategori tingkat kesukarannya ditunjukkan pada Tabel 2. 

Tabel 2. Pengklasifikasian Kategori Tingkat Kesukaran Soal

(Sumber: Arikunto, 2006:210)

\begin{tabular}{ll}
\hline Nilai $\boldsymbol{P}$ & Kategori \\
\hline$P<0,30$ & Sukar \\
$0,30 \leq P \leq 0,70$ & Sedang \\
$P>0,70$ & Mudah \\
\hline
\end{tabular}

\section{Uji Daya Beda}

Uji pembeda soal adalah kemampuan suatu soal dalam membedakan antara siswa berkemampuan tinggi dengan siswa berkemampuan rendah. Cara yang digunakan sama dengan menentukan tingkat kesukaran, hanya saja sebelum dilakukan penghitungan terlebih dahulu dilakukan pengurutan skor yang diperoleh dari yang tinggi sampai yang rendah. Rumus yang digunakan untuk mencari daya beda soal sebagai berikut.

Uji daya beda $=\boldsymbol{P}_{\text {kemampuan tinggi }}-\boldsymbol{P}_{\text {kemampuan rendah }}$ (3)

Adapun pengklasifikasian kategori daya beda ditunjukkan pada Tabel 3.

Tabel 3. Pengklasifikasian Kategori Daya Beda

\begin{tabular}{ll}
\hline \multicolumn{1}{c}{ Nilai $\boldsymbol{P}$} & \multicolumn{1}{c}{ Kategori } \\
\hline $0,00-0,20$ & jelek (poor) \\
$0,21-0,40$ & cukup (satisfactory) \\
$0,41-0,70$ & baik (good) \\
$0,71-1,00$ & baik sekali (excellent) \\
\hline (Sumber: Arikunto, 2006: 218$)$ &
\end{tabular}

\section{Pengumpulan Data}

Data penelitian diperoleh dengan langkah-langkah sebagai berikut.

a. Tes Awal (pre-test), dilakukan untuk mengetahui hasil belajar siswa sebelum penerapan strategi pembelajaran.

b. Tes Akhir (post-test), untuk mengetahui hasil belajar siswa setelah perlakuan dengan strategi pembelajaran.

c. Observasi, dilaksanakan melalui pengamatan kerjasama selama kegiatan pembelajaran dengan lembar observasi.

d. Angket, diberikan kepada guru dan siswa untuk mengetahui respons mereka terhadap penerapan strategi pembelajaran. 
Nur Efendi

\section{Analisis Data}

Data yang telah terkumpulkan dianalisis dengan menggunakan statistik sebagai berikut.

a. Analisis deskriptif, untuk melihat deskripsi persentase kemampuan metakognitif dan hasil belajar siswa sebelum dan sesudah pembelajaran.

b. Anacova (Analysis of Covarians) dengan rancangan faktorial $(4 \times 2)$ untuk menguji hipotesis penelitian yang ditetapkan.

\section{HASIL DAN PEMBAHASAN}

Hasil

Kemampuan metakognitif merupakan salah satu variabel hasil belajar siswa yang dianalisis dalam penelitian ini. Kemampuan metakognitif siswa diukur dengan menggunakan rubrik penilaian keterampilan metakognitif, yang dikembangkan oleh Corebima (2008). Rubrik tersebut digunakan untuk menilai tes esai siswa yang dilakukan sebelum dan sesudah penerapan strategi pembelajaran (pre-post test). Data yang diperoleh kemudian dianalisis dengan menggunakan analisis kovarians.
Pengaruh Strategi Pembelajaran terhadap Kemampuan Metakognitif Siswa

Hasil analisis kovarians pada Tabel 4 menunjukkan bahwa $\mathrm{F}$ hitung variabel strategi pembelajaran adalah sebesar 7,68 dengan tingkat signifikansi 0,00 yang masih lebih kecil dibandingkan alpha 0,05 yang digunakan sebagai standar pengujian. Dengan demikian $\mathrm{H}_{0}$ ditolak dan hipotesis penelitian yang menyatakan bahwa terdapat pengaruh strategi pembelajaran terhadap kemampuan metakognitif siswa diterima, artinya penerapan strategi pembelajaran yang berbeda menyebabkan perolehan nilai kemampuan metakognitif yang berbeda pula.

Dengan adanya pengaruh yang signifikan ini, maka analisis dilanjutkan dengan uji LSD untuk mengetahui perbedaan rata-rata nilai kemampuan metakognitif siswa pada setiap level strategi pembelajaran. Hasil analisis selengkapnya disajikan pada Tabel 5 . 
Tabel 5. Ringkasan Hasil Uji LSD Strategi Pembelajaran terhadap Skor Nilai Kemampuan Metakognitif Siswa.

\begin{tabular}{lllll}
\hline Strategi Pembelajaran & Pre-test & Post-test & PosCor & LSD \\
\hline Konvensional & 10,32 & 73,93 & 74,36 & $\mathrm{a}$ \\
Reciprocal Teaching $(R T)$ & 12,10 & 75,65 & 75,45 & $\mathrm{ab}$ \\
Think Pair Share $(T P S)$ & 11,76 & 76,85 & 76,44 & $\mathrm{bc}$ \\
RT+TPS & 12,46 & 78,07 & 77,73 & $\mathrm{c}$ \\
\hline
\end{tabular}

Ket. Huruf yang sama pada kolom yang sama menunjukkan tidak adanya perbedaan, sedangkan huruf yang berbeda menunjukkan adanya perbedaan.

Berdasarkan Tabel 5, terlihat bahwa rata-rata terkoreksi nilai kemampuan metakognitif siswa yang paling tinggi pada kelompok strategi pembelajaran Reciprocal Teaching dipadukan Think Pair Share $(R T+T P S)$ dengan nilai 77,73, kemudian diikuti Think Pair Share (TPS) dengan nilai 76,44 , Reciprocal Teaching $(R T)$ dengan nilai 75,45 , dan konvensional dengan nilai 74,36 .

Berdasarkan perbedaan notasi, dapat dijelaskan pula bahwa rata-rata terkoreksi nilai kemampuan metakognitif siswa pada kelompok strategi pembelajaran Reciprocal Teaching dipadukan Think Pair Share $(R T+T P S)$ tidak berbeda nyata dan lebih tinggi 1,65\% dari Think Pair Share (TPS), tetapi berbeda nyata dan lebih tinggi 2,92\% dari Reciprocal Teaching $\quad(R T), \quad 4,33 \% \quad$ dari Konvensional.

Selanjutnya, hasil uji LSD juga menunjukkan bahwa rata-rata terkoreksi nilai kemampuan metakognitif pada kelompok strategi pembelajaran Think Pair Share (TPS) tidak berbeda nyata dan lebih tinggi 1,29 \% dari Reciprocal Teaching (RT), tetapi berbeda nyata dan lebih tinggi 2,72\% dari konvensional. Sedangkan rata-rata terkoreksi nilai kemampuan metakognitif strategi pembelajaran Reciprocal Teaching (RT) tidak berbeda nyata dan lebih tinggi $1,45 \%$ dari konvensional.

\section{Pengaruh Kemampuan Akademik terhadap Kemampuan Metakognitif Siswa}

Hasil analisis kovarians menunjukkan bahwa $\mathrm{F}$ hitung variabel kemampuan akademik adalah 3,98 dengan tingkat signifikansi 0,047 yang masih lebih kecil dibandingkan dengan alpha 0,05 sehingga Ho ditolak. Dengan ditolaknya $\mathrm{H}$, maka hipotesis penelitian yang menyatakan bahwa terdapat pengaruh kemampuan akademik siswa terhadap kemampuan metakognitif siswa diterima, artinya 
kemampuan akademik siswa yang bahwa rata-rata terkoreksi nilai berbeda menyebabkan perbedaan nilai kemampuan metakognitif siswa kemampuan metakognitif. Hasil kelompok siswa akademik atas adalah analisis selengkapnya disajikan pada 76,53 berbeda nyata dan lebih tinggi Tabel 6. Berdasarkan perbedaan notasi $1,39 \%$ dari siswa akademik bawah pada tabel tersebut, dapat dijelaskan 75,46.

Tabel 6. Ringkasan Hasil Uji LSD Kemampuan Akademik terhadap Skor Nilai Kemampuan Metakognitif Siswa.

\begin{tabular}{lllll}
\hline Kemampuan Akademik & Pre-test & Post-test & PosCor & LSD \\
\hline Akademik Bawah & 10,77 & 75,32 & 75,46 & $\mathrm{a}$ \\
Akademik Atas & 12,55 & 76,94 & 76,53 & $\mathrm{~b}$ \\
\hline
\end{tabular}

Ket. Huruf yang sama pada kolom yang sama menunjukkan tidak adanya perbedaan, sedangkan huruf yang berbeda menunjukkan adanya perbedaan.

Interaksi Strategi Pembelajaran dan

Kemampuan Akademik terhadap

\section{Kemampuan Metakognitif Siswa}

Hasil analisis kovarians menunjukkan bahwa $\mathrm{F}$ hitung variabel interaksi strategi pembelajaran dengan kemampuan akademik siswa adalah 3,17 dengan tingkat signifikansi 0,025 yang masih lebih kecil dibandingkan dengan alpha 0,05 sehingga $\mathrm{H}_{0}$ ditolak. Dengan ditolaknya Ho, maka hipotesis penelitian yang menyatakan bahwa terdapat pengaruh interaksi strategi pembelajaran dan kemampuan akademik siswa terhadap kemampuan metakognitif siswa diterima. Hasil uji LSD dari interaksi tersebut dapat disajikan pada Tabel 7. Berdasarkan perbedaan notasi pada tabel tersebut, dapat dijelaskan bahwa rata-rata terkoreksi nilai kemampuan metakognitif siswa yang paling tinggi adalah kelompok strategi pembelajaran $R T+T P S$ akademik atas dengan nilai 78,93 dan nilai terkoreksi terendah strategi pembelajaran Konvensional akademik atas dengan nilai 74,27.

Tabel 7. Ringkasan Hasil Uji LSD Interkasi Strategi dan Tingkat Kemampuan Akademik terhadap Skor Nilai Kemampuan Metakognitif.

\begin{tabular}{llllll}
\hline Strategi Pembelajaran & Akademik & Pre-test & Post-test & PosCor & LSD \\
\hline Konvensional & Atas & 11,51 & 73,58 & 74,27 & $\mathrm{a}$ \\
Konvensional & Bawah & 9,13 & 74,28 & 74,46 & $\mathrm{a}$ \\
Think Pair Share $($ TPS $)$ & Bawah & 10,39 & 74,84 & 75,07 & $\mathrm{ab}$ \\
Reciprocal Teaching $(R T)$ & Atas & 12,73 & 75,55 & 75,10 & $\mathrm{ab}$ \\
Reciprocal Teaching $(R T)$ & Bawah & 11,47 & 75,76 & 75,81 & $\mathrm{ab}$
\end{tabular}




\begin{tabular}{llllll}
$(R T+T P S)$ & Bawah & 12,09 & 76,38 & 76,53 & bc \\
Think Pair Share (TPS) & Atas & 13,13 & 78,86 & 77,82 & cd \\
$($ RT+TPS $)$ & Atas & 12,84 & 79,77 & 78,93 & d \\
\hline
\end{tabular}

Ket. Huruf yang sama pada kolom yang sama menunjukkan tidak adanya perbedaan, sedangkan huruf yang berbeda menunjukkan adanya perbedaan.

Berdasarkan notasi LSD pada

Tabel 7 dapat dijelaskan sebagai berikut.

a. Rata-rata terkoreksi nilai kemampuan metakognitif siswa kelompok strategi pembelajaran $R T+T P S$ akademik atas tidak berbeda nyata dan lebih tinggi 1,42\% dari TPS akademik atas, tetapi berbeda nyata dan lebih tinggi dengan 4,86\% dari $R T$ akademik atas, dan 5,91\% dari Konvensional akademik atas. Selanjutnya, untuk rata-rata terkoreksi TPS akademik atas berbeda nyata dan lebih tinggi 3,50\% dari $R T$ akademik atas dan dan $4,56 \%$ dari konvensional akademik atas, sedangkan rata-rata terkoreksi $R T$ akademik atas tidak berbeda nyata dan lebih tinggi $1,10 \%$ dari konvensional atas.

b. Rata-rata terkoreksi nilai kemampuan metakognitif $R T+T P S$ akademik bawah tidak berbeda nyata dengan $R T$ akademik bawah dan TPS akademik bawah, tetapi berbeda nyata dan lebih tinggi 2,71\% dari konvensional akademik bawah. c. Rata-rata terkoreksi nilai kemampuan metakognitif siswa kelompok strategi pembelajaran $R T+T P S$ akademik atas berbeda nyata dan lebih tinggi 3,05\% dari $R T+T P S$ akademik bawah. Ratarata terkoreksi TPS akademik atas berbeda nyata dan lebih tinggi 3,54\% TPS akademik bawah. Ratarata terkoreksi $R T$ akademik atas tidak berbeda nyata dan lebih rendah $0,94 \%$ dari $R T$ akademik bawah. Rata-rata terkoreksi Konvensional akademik atas tidak berbeda nyata dan lebih rendah $0,25 \%$ dari konvensional akademik bawah.

PEMBAHASAN

Pengaruh Strategi Pembelajaran terhadap Kemampuan Metakognitif Siswa

Berdasarkan uji anakova pengaruh strategi pembelajaran terhadap kemampuan metakognitif siswa, maka hasil analisis yang menunjukkan bahwa terdapat pengaruh strategi pembelajaran Reciprocal Teaching dipadukan Think Pair Share 
(RT+TPS) terhadap kemampuan metakognitif siswa diterima. Rata-rata skor nilai kemampuan metakognitif siswa dengan strategi pembelajaran $R T+T P S$ lebih tinggi dibandingkan dengan strategi pembelajaran konvensional. Hasil yang sama juga terlihat pada strategi pembelajaran Think Pair Share (TPS) dan Reciprocal Teaching $(R T)$, di mana rata-rata skor nilai kemampuan metakognitif siswa untuk kedua strategi pembelajaran tersebut lebih tinggi dari strategi pembelajaran konvensional.

Pada ketiga strategi pembelajaran tersebut $(R T+T P S, R T$, dan TPS), siswa menunjukkan partisipasi yang aktif dalam kegiatan pembelajaran. Mereka sangat antusias dalam mengerjakan LKS yang disediakan sesuai dengan tahapan pembelajaran yang digunakan. Siswa merasa mendapat kesempatan untuk dapat menyampaikan pendapat, sesuai dengan apa yang ada dalam pikirannya. Terutama pada strategi pembelajaran $\quad R T+T P S, \quad$ siswa mempunyai kesempatan diskusi secara intensif pada kelompok berpasangannya dan antar-kelompok berpasangan dalam kelas. Dengan demikian, siswa dapat menjadi pebelajar bagi dirinya sendiri maupun teman-temannya. Suasana pembelajaran ini terlihat pada materi pelajaran keanekaragaman hayati (biodiversitas) maupun materi lainnya. Siswa terlihat sangat serius dalam perdebatan tentang materi yang dibahas, seperti: keanekaragaman tingkat gen, tingkat spesies, tingkat ekosistem, dan usaha pelestarian keanekaragaman hayati Indonesia. Suasana ini jarang ditemukan pada strategi pembelajaran konvensional, karena pada strategi pembelajaran konvensional guru lebih banyak mendominasi pembelajaran dengan menjelaskan materi kepada siswa, sehingga kesempatan siswa untuk berpartisipasi dalam diskusi menjadi kurang. Pada pembelajaran konvensional frekuensi siswa dalam mengajukan pertanyaan maupun menjawab pertanyaan masih rendah.

Hasil penelitian ini sesuai dengan pendapat Silver, dkk. (1996) yang menyatakan bahwa dengan strategi interpersonalpada Reciprocal Teaching $(R T)$, siswa memperoleh pengetahuan baru dan melatih keterampilan penting melalui berbagi pribadi, kesadaran individu dan sosial, pembelajaran kelompok terfokus, sehingga dapat menambah wawasandan pengetahuan sebelumnya. Pendapat yang lain juga 
disampaikan oleh Costa dan O'Leary dalam Warouw (2009) yang menjelaskan bahwa siswa dapat meningkatkan kemampuan metakognitif lebih baik jika berpartisispasi dalam kelompokkelompok belajar kooperatif. Hasil penelitian yang juga berhubungan dengan keterampilan metakognisi seperti hasil penelitian Susantini (2004) menyatakan dalam penelitiannya bahwa melalui metakognisi siswa mampu menjadi pebelajar mandiri, menumbuhkan sikap jujur, berani mengakui kesalahan, dan dapat meningkatkan hasil belajar secara nyata. Demikian pula hasil penelitian Suratno (2009), menunjukkan bahwa keterampilan metakognisi bermanfaat bagi siswa yang mengalami pembelajaran melalui model pembelajaran kooperatif (Jigsaw-RT). Pendapat yang sama, untuk mempertegas berbagai penelitian tersebut juga disampaikan Sarwinda (2011) yang menyatakan bahwa strategi pembelajaran Reciprocal Teaching Dipadukan Think Pair Share(RT+TPS) memberikan peluang kepada siswa untuk dapat meningkatkan kemampuan berpikir kreatif.
Pengaruh Kemampuan Akademik terhadap Kemampuan Metakognitif Siswa

Berdasarkan uji anakova pengaruh kemampuan akademik terhadap kemampuan metakognitif siswa, maka hasil analisis yang menunjukkan bahwa terdapat pengaruh kemampuan akademik siswa terhadap kemampuan metakognitif siswa diterima. Rata-rata skor nilai kemampuan metakognitif siswa kelompok siswa berkemampuan akademik atas lebih tinggi dibandingkan dengan siswa akademik bawah. Pada kegiatan pembelajaran juga terlihat bahwa siswa pada kelompok akademik atas lebih aktif dan bertanggungjawab pada tugas yang harus diselesaikan pada LKS sesuai dengan tahapan pembelajaran yang digunakan, berpartisipasi secara aktif dalam diskusi, sedangkan siswa pada kelompok akademik bawah cenderung pasif, sering bercanda, dan kurang bersemangat pada kegiatan pembelajaran, terutama pada materi yang membutuhkan tingkat pemikiran yang tinggi.

Temuan penelitian ini sejalan dengan Tumbel (2011) yang menjelaskan bahwa faktor intelegensi 
merupakan salah satu faktor yang efektif dalam mempengaruh keberhasilan pembelajaran. Siswa yang cerdas akan lebih berhasil dalam kegiatan belajar, karena lebih mudah menangkap dan memahami pelajaran serta lebih mudah dalam mengingatnya. Dijelaskan pula lebih lanjut bahwa siswa yang cerdas akan lebih mudah berpikir kreatif dan lebih cepat mengambil keputusan, berbeda dengan siswa yang kurang cerdas atau lamban cenderung memiliki kemampuan berpikir kreatif yang rendah (Sarwinda, 2011).

Rujukan tersebut memberikan gambaran bahwa siswa berkemampuan akademik tinggi memiliki kesadaran metakognitif yang lebih baik, sehingga dapat menggunakan untuk mengontrol proses-proses kognitif dan memiliki kesadaran dalam memotivasi kegiatan belajar yang dilakukan. Hal ini sejalan dengan Peters (2000) yang menyatakan bahwa keterampilan metakognitif bermanfaat untuk menjadikan siswa menjadi pebelajar mandiri, karena mendorong mereka menjadi dirinya sendiri serta menjadi penilai atas pemikiran dan pembelajaran sendiri. Metakognitif bermanfaat untuk pencapaian akademik siswa dan merupakan salah satu cara untuk memahami perbedaan pencapaian akademik dari siswa (Tumbel, 2011). Hal ini senada dengan pendapat Yuwono (2012) yang menyatakan bahwa sejauh mana kebolehan metakognitif mempengaruhi pencapaian, sebenarnya sangat tergantung pada pola motivasi siswa.

Interaksi Strategi Pembelajaran dan Kemampuan Akademik terhadap

\section{Kemampuan Metakognitif Siswa}

Berdasarkan uji anakova pengaruh strategi pembelajaran dan kemampuan akademik terhadap kemampuan metakognitif siswa, maka hasil analisis yang menunjukkan bahwa terdapat pengaruh interaksi strategi pembelajaran dan kemampuan akademik siswa terhadap kemampuan metakognitif siswa diterima. Rata-rata skor nilai kemampuan metakognitif siswa kelompok strategi pembelajaran $R T+T P S$ berkemampuan akademik atas berbeda nyata dan lebih tinggi dibandingkan dengan $R T$ dan Konvensional berkemampuan akademik atas, tetapi tidak berbeda nyata dan lebih tinggi dari TPS akademik atas. Tingginya nilai kemampuan metakognitif ini 
merupakan implikasi dari penerapan sintaks (tahapan) strategi pembelajaran $R T+T P S . \quad$ Strategi pembelajaran $R T+T P S$ merupakan hasil pengembangan perangkat pembelajaran yang memadukan strategi pembelajaran Reciprocal Teaching (RT)dengan Think Pair Share (TPS). Jika dilihat berdasarkan sintaks pada $R T+T P S$, memperlihatkan ciri $R T$ yaitu membaca dan mencari ide pokok bacaan, membuat pertanyaan dan mengidentifikasi kata-kata sulit, menjawab pertanyaan dan mengklarifikasi kata-kata sulit, membuat rangkuman, dan memprediksi dalam kelompok pasangan. Penambahan unsur TPS adalah saling berdiskusi untuk menyamakan persepsi dalam perumusan ide pokok bacaan, pertanyaan dan jawaban, identifikasi dan klarifikasi kata-kata sulit, dilanjutkan merangkum, dan prediksi (RT-Think, RT-Pair) untuk dipresentasikan secara berbagi (RTShare) dengan kelompok berpasangan lainnya dalam kelas. Kegiatan pembelajaran ini memperlihatkan pola pembelajaran yang memberdayakan kemampuan metakognitif.

Wujud dari keberhasilan strategi pembelajaran $R T+T P S$ juga terlihat dalam setiap kegiatan pembelajaran yang telah disampaikan, contoh: pada materi pelajaran dunia tumbuhan (Kingdom Plantae), siswa kelihatan serius mengerjakan LKS sendiri dengan membaca teks bacaan, membuat pertanyaan dan identifikasi kata-kata sulit, menjawab dan mengklarifikasi kata-kata sulit (RT-Think). Guru aktif mendatangi siswa dari kelompok berpasangan yang satu ke kelompok berpasangan lainnya untuk memantau kegiatan pembelajaran, sedangkan siswa melaksanakan kegiatan pembelajaran dengan baik, membaca dan memahami teks bacaan yang dibagikan dan mengerjakan LKS sesuai dengan tahapan strategi pembelajaran secara seksama dengan kelompok berpasangannya (RT-Pair). Pada tahap $R T$-Share, kegiatan berlanjut dengan guru memberikan sedikit ulasan tentang materi untuk menstimuli seluruh kelompok berpasangan siswa untuk aktif berdiskusi dalam kelas dengan menggunakan peta konsep, siswa terlihat aktif dalam diskusi tersebut. Keadaan ini sejalan dengan pemikiran Nur (1997) yang menyatakan bahwa apabila seorang siswa berorientasi pada visual, maka membuat suatu peta konsep merupakan cara baik baginya 
untuk memahami dan mengikat sejumlah besar informasi baru.

Hasil dari pembahasan diskusi tersebut, yaitu: a) siswa mampu mengklasifikasikan bahwa dunia tumbuhan (Kingdom Plantae) dibedakan menjadi: kelompok lumut (Bryophyta), paku (Pterydophyta), dan tumbuhan berbiji (Spermatophyta), b) siswa dapat memahami ciri-ciri tumbuhan tersebut, c) siswa dapat menjelaskan peranan kelompok tumbuhan tersebut bagi kehidupan manusia. Kegiatan yang sama, juga terjadi pada materi pelajaran untuk keanekaragaman hayati (Biodiversitas), dunia hewan (Kingdom Animalia), ekosistem, serta pencemaran dan perubahan lingkungan. Kegiatan pembelajaran ini, sejalan dengan pandangan Suharlik (2011) yang menyatakan bahwa strategi pembelajaran Reciprocal Teaching dipadukan Think Pair Share (RT+TPS) dapat diterapkan dalam pembelajaran biologi pada materi keanekaragaman mahluk hidup.

Pada sintaks RT-Think dapat meningkatkan kesadaran siswa untuk memotivasi diri dalam berpikir bagaimana cara untuk memahami pengetahuan yang akan dicapai. Hal ini sesuai dengan pandangan Blakey, dkk. (1990), yang mengemukakan metakognisi ialah berpikir tentang pemikiran, mengetahui "apa yang kita ketahui" dan "apa yang tidak kita ketahui". Selanjutnya Pierce (2004) mengemukakan metakognitif sebagai suatu apresiasi dari apa yang telah kita ketahui, bersama-sama dengan suatu pengertian dari tugas-tugas pembelajaran dan apa yang pengetahuan dan keterampilanketerampilan itu diperlukan, yang dikombinasikan dengan ketangkasan untuk membuat kesimpulan yang benar, tentang bagaimana cara menerapkan pengetahuannya yang strategis pada situasi terentu.

Pada sintaks RT-Pair dan RTShare dapat meningkatkan kemampuan siswa untuk menggali, menyaring, dan menanyakan ide-ide baru. Tingkat diskusi dan perdebatan dalam kelompok berpasangan maupun kelompok lainnya dalam kelas dapat meningkatkan kemampuan metakognitif siswa, berkomunikasi, dan interaksi sosial. Hal ini sejalan dengan pemikiran Mulbar (2008) yang menyatakan bahwa metakognitif memiliki dua komponen, yaitu: a) pengetahuan metakognitif 
(metacognitive knowledge) dan b) keterampilan metakognitif (metacognitive skills). Pengetahuan metakognitif berkaitan dengan pengetahuan deklaratif, pengetahuan prosedural dan pengetahuan kondisional, sedangkan keterampilan kognitif berkaitan dengan keterampilan perencanaan, prediksi, monitoring, dan evaluasi.

Rata-rata terkoreksi nilai kemampuan metakognitif $R T+T P S$ akademik bawah tidak berbeda nyata dengan $R T$ akademik bawah dan TPS akademik bawah, tetapi berbeda nyata dan lebih tinggi $2,71 \%$ dari konvensional akademik bawah. Keadaan ini menunjukkan pada siswa berkemampuan akademik bawah memiliki kemampuan metakognitif yang rata-rata rendah sehingga tingkat perbedaan mereka tentang berpikir terhadap apa yang mereka pikirkan masih belum kelihatan, namun perbedaan ini lebih nyata terjadi pada strategi pembelajaran konvensional. Pada pembelajaran ini rata-rata skor nilai kemampuan metakognitif siswa ada pada tingkat yang paling rendah yaitu 74,46, dibandingkan dengan ketiga kelompok strategi tersebut. Artinya, semakin siswa tidak distimulus dengan pola pikir yang menggunakan keterampilan metakognitif mereka yang ada pada ketiga strategi pembelajaran $(R T+T P S, \quad T P S, \quad R T), \quad$ maka kemamampuan metakognitif siswa akan semakin rendah. Flavel (1997) dalam Veenman (2006) mengemukakan bahwa metakognitif memainkan peran dalam proses pembelajaran. Selanjutnya Sumampouw (2011), Yuwono (2012), mengemukakan pula bahwa terdapat hubungan positif antara metakognitif dan pencapaian akademik. Pada rata-rata skor nilai kemampuan metakognitif siswa pada kelompok strategi pembelajaran $R T$ berkemampuan akademik atas tidak berbeda nyata dan lebih rendah $0,94 \%$ dari $R T$ akademik bawah, menunjukkan bahwa peranan guru dalam mengelola pembelajaran sangat diperlukan, sehingga kemampuan guru dalam memahami, menginovasi, dan menerapkan sintaks strategi pembelajaran menjadi kunci keberhasilan pembelajaran tersebut. Keadaan ini menunjukkan bahwa meskipun strategi pembelajaran sama dengan kemampuan guru dalam mengelola pembelajaran tidak sama, maka hasil kemampuan metakognitif siswa juga tidak sama. Menurut 
Achmadi dalam Khabibah (1999: 27), kelemahan pembelajaran Reciprocal Teaching adalah:a) butuh waktu yang lama, b) sangat sulit diterapkan jika pengetahuan siswa tentang materi prasyarat kurang, c) adakalanya siswa tidak mampu akan semakin tidak suka dengan pembelajaran tersebut, d) tidak mungkin seluruh siswa akan mendapat giliran untuk menjadi "guru siswa".

\section{PENUTUP}

\section{Simpulan}

Berdasarkan analisis data dan pembahasan maka dapat diambil beberapa kesimpulan sebagai berikut.

1. Terdapat pengaruh strategi pembelajaran dan kemampuan akademik terhadap kemampuan metakognitif siswa.

a. Rata-rata skor nilai kemampuan metakognitif siswa pada strategi pembelajaran Reciprocal Teaching dipadukan Think Pair Share $(R T+T P S)$ berbeda nyata dan lebih tinggi dari Reciprocal Teaching (RT) dan konvensional, tetapi tidak berbeda nyata dan lebih tinggi dari Think Pair Share (TPS).

b. Rata-rata skor nilai kemampuan metakognitif siswa berkemampuan akademik atas berbeda nyata dan lebih tinggi dari siswa akademik bawah.

c. Rata-rata skor nilai kemampuan metakognitif siswa kelompok strategi pembelajaran $R T+T P S$ akademik atas berbeda nyata dan lebih tinggi $R T$ akademik atas dan konvensional akademik atas, tetapi tidak berbeda nyata dan lebih tinggi dari TPS akademik atas. Rata-rata terkoreksi nilai kemampuan metakognitif siswa kelompok strategi pembelajaran $R T+T P S$ akademik atas berbeda nyata dan lebih tinggi dari $R T+T P S$ akademik bawah.

2. Penerapan strategi pembelajaran $R T+T P S$ memiliki hasil yang lebih baik dalam meningkatkan kemampuan metakognitif dan hasil belajar biologi siswa, jika dibandingkan dengan strategi $R T$, TPS, maupun Konvensional pada siswa berkemampuan akademik atas maupun siswa berkemampuan akademik bawah.

\section{Saran}

Berdasarkan kesimpulan yang
telah dijelaskan, maka dapat


dikemukakan beberapa saran atau rekomendasi penelitian sebagai berikut.

1. Bagi guru biologi, strategi pembelajaran Reciprocal Teaching Dipadukan Think Pair Share (RT+TPS) terbukti memiliki hasil yang lebih baik dalam meningkatkan kemampuan metakognitif belajar biologi siswa, jika dibandingkan dengan strategi pembelajaran Konvensional, sehingga dapat digunakan secara luas dalam pembelajaran biologi dan salah satu alternatif pilihan dalam mengelola pembelajaran di dalam kelas.

2. Bagi pengambil kebijakan (stake holder), pada penelitian ini dihasilkannya perangkat pembelajaran Reciprocal Teaching Dipadukan Think Pair Share $(R T+T P S)$, Reciprocal Teaching(RT), dan Think Pair Share (TPS) dapat dijadikan pertimbangan dalam mengambil keputusan untuk kepentingan pendidikan, seperti: peningkatan kualitas tenaga pendidik ini dengan cara seminar maupun pelatihan (workshop) penerapan strategistrategi pembelajaran inovatif serta perubahan-perubahan paradigma dalam pendidikan, di mana dengan program ini diharapkan pembelajaran dapat lebih maksimal dan meningkatkan kemampuan metakognitif belajar biologi siswa.

3. Bagi peneliti lanjutan maupun guru, temuan penelitian ini dapat menjadi penelitian awal bagi peneliti yang ingin mengkaji strategi pembelajaran Reciprocal TeachingDipadukan Think Pair Share $(R T+T P S)$ dengan pola pemberdayaan kemampuan metakognitif pada siswa atau dipadukan dengan strategi pembelajaran lain untuk mereduksi kejenuhan yang dialami siswa selama pembelajaran.

\section{DAFTAR PUSTAKA}

Anderson, L.W., Krathwohl, D.R., Airasian, P.W., Cruikshank, K.A., Mayer, R.E., Pintrich, P.R., James R. \& Wittrock, M.C. (Eds.). (2001). A taxonomy for learning, teaching, and assessing: a revision of bloom's taxonomy of education objectives. New York: Addison Wesley Longman, Inc.

Arikunto, S. (2006). Prosedur penelitian suatu pendekatan praktik. Jakarta: Rineka Cipta.

Blakey, Elaine, S. \& Sheila. (1990). Developing metacognition. Erick Digest. EIC Clearinghouse of Information 
Resources Syracuse NY:ED 327218.

(http://amazon.com/xc/obidos/re direct.tag) diakses 8 Januari 2010.

Corebima. A.D. (2000). Pemberdayaan penalaran siswa untuk menyiapkan generasi berkualitas. Makalah Seminar disampaikan di SLTPN 2 Malang.

Corebima, A.D. (2008). Pemahaman tentang asesmen autentik. Makalah disajikan dalam Rangka Diklat Sertifikasi Guru. Malang: Universitas Negeri Malang.

Departemen Pendidikan Nasional Republik Indonesia. (2004). Kurikulum pendidikan menengah. garis-garis besar program pengajaran (GBPP) sekolah lanjutan tingkat atas. Jakarta: DEPDIKNAS.

Efendi, N. (2005). Penerapan pengajaran terbalik (reciprocal teaching) untuk menuntaskan hasil belajar siswa sltp pada pokok bahasan perkembangbiakan tumbuhan. Tesis tidak diterbitkan. Surabaya: Pascasarjana UNESA.

Efendi, N. (2011). Deskripsi umum profil guru dan karakteristik pembelajaran biologi dalam meningkatkan hasil belajar siswa di SMA Kabupaten Sidoarjo. Makalah Seminar Nasional disampaikan di FMIPA UNESA pada Tanggal 10 Desember 2011. Surabaya: Unesa University Press.
Galyam, N. \& Le Grange, L. (2005). Improving thinking skills in science of learners with (dis) abilities. South African Journal Education. Vol 25 (4) 239-246.

Hart, D. (1994). Authentic assessment a hand book for educators. California, New York: AddisonWesley Publishing Company.

Hutabarat, D. (2005). Pengembangan perangkat pembelajaran biologi sma, yang berorientasi pendekatan reciprocal teaching dalam bahan kajian sistem reproduksi. Tesis tidak diterbitkan. Surabaya: Pascasarjana UNESA.

Ibrahim, M. (2008). Pembelajaran sains: reciprocal teaching (pembelajaran resiprok). (sainsmuslimin.blogspot.com/... .pembelajaran-sains.htmlcached-similar) diakses 22 Oktober 2010.

Kardi, S. (2002). Strategi motivasi model ARCS. Surabaya: Universitas Negeri Surabaya.

Khabibah, S. (1999). Pengembangan perangkat pembelajaran bedasarkan prinsip pengajaran terbalik pada pokok bahasan persamaan linear di SMU. Tesis tidak diterbitkan. Surabaya: Pascasarjana Universitas Negeri Surabaya.

Mulbar, U. (2008). Metakognisi mahasiswa dalam menyelesaikan masalah matematika. Usmanmulbar. Files.

Wordpress.com/2008/04/makala 
h-seminar-nasional di bandungusman- mulbar.doc.

Nindiasari, H. (2004). Pembelajaran metakognitif untuk meningkatkan pemahaman dan koneksi matematik siswa smu ditinjau dari perkembangan kognitif siswa. Tesis tidak diterbitkan. Malang: Program Pascasarjana UM.

Nur, M. (1997). Keterampilanketerampilan metakognitif. Makalah disampaikan bulan Desember 1997 pada Workshop Penelitian Elqa IKIP Surabaya.

Palincsar, A. \& Brown, A. (1984). Reciprocal teaching of comprehension-fostering and comprehension-monitoring activities. cognition and instruction, 2, 117-175.

Pierce, W. (2004). Metacognition: study strategies, monitoring, and motivation. a greatly expanded text version of workshop presented November 17, 2004, at Prince George's Community College. (http:// academic.pgcc.edu/wpierce/MCCCCTR/metacognit ion.htm) diakses 15 Nopember 2009.

Peters, M. (2000). Does constructivist epistemology have a place in nurse education. Journal of nursing education 39, no. 4: 166-170.

Sarwinda, W. (2011). Pengaruh Strategi Pembelajaran Think Pair Share Dipadukan Reciprocal Teaching dan Kemampuan Akademik yang
Berbeda terhadap Hasil Belajar Kognitif dan Keterampilan Berpikir Kreatif pada Siswa SMA Negeri 1 Batu dan SMA Negeri 1 Grati. Tesis tidak dipublikasikan. Malang: Universitas Negeri Malang.

Sidi, I. J. (2001). Menuju masyarakat belajar: menggagas paradigma baru pendidikan. Jakarta: Logos Wacana Ilmu.

Silver, H.F., Hanson, J.R., Strong, R.W. \& Schwartz, P.B. (1996). Teaching styles \& strategies. Trenton, NJ: The Thoughtful Education Press.

Slavin, R.E. (1994). Educational psychology: theories and practice. Fourth Edition. Massachussetts: Allyn and Bacon Publishers.

Sugiyono. (2006). Statistika untuk penelitian. Bandung: Alfabeta.

Sugiyono. (2007). Metode penelitian kuantitatif, kualitatif dan $R \& D$, Bandung, Alfabeta.

Suharlik. (2011). Pengaruh Strategi Pembelajaran Integrasi ThinkPair-Share dan Reciprocal Teaching terhadap Hasil Belajar Kognitif dan Retensi Biologi Siswa Berkemampuan Akademik Berbeda di SMAN 1 Batu. Tesis tidak diterbitkan. Malang: Universitas Negeri Malang.

Sumampouw, M.H. (2011). Kajian perkuliahan dan asesmen genetika dalam memberdayakan keterampilan metakognitif, berpikir tingkat tinggi, 
keterampilan proses, dan retensi mahasiswa jurusan biologi S1 dan S2 Universitas Negeri Malang. Disertasi tidak diterbitkan. Malang: Universitas Negeri Malang.

Suprijono, A. (2009). Cooperative learning: teori \& aplikasi PAIKEM. Yogyakarta: Pustaka Pelajar.

Suratno. (2009). Pengaruh strategi kooperatif jigsaw dan reciprocal teaching terhadap keterampilan metakognisi dan hasil belajar biologi siswa SMA berkemampuan atas dan bawah di Jember. Disertasi tidak diterbitkan. Malang: Universitas Negeri Malang.

Susantini, E. (2004). Memperbaiki kualitas proses belajar genetika melalui strategi metakognitif dalam pembelajaran kooperatif pada siswa SMU. Disertasi tidak diterbitkan. Malang: Universitas Negeri Malang.

Tilaar, H.A.R. (2002). Membenahi pendidikan nasional. Jakarta: Rineka Cipta.

Tuckman, B.W. (1988). Conducting educational reseach. Second Edition. Boston: Allyn and Bacon A Viacom Company.

Tumbel, M.F. (2011). Pengaruh strategi pembelajaran cooperatif script plus problem possing terhadap keterampilan metakognitif, kemampuan berpikir dan pemahaman konsep pada siswa berkemampuan akademik tinggi dan rendah pada SMA di Kota Bitung.
Disertasi tidak diterbitkan.

Malang: Universitas Negeri Malang.

Veenman, M. V. J. (2006). Metacognition and learning: conceptual and methodological considerations. Received:

December 08, 2005. Bussiness Media, Inc. 2006. (www:// springerlink.com) diakses 2 Oktober 2009.

Warouw, Z. (2009). Pengaruh pembelajaran metakognitif dengan strategi cooperative script, dan reciprocal teaching pada kemampuan akademik berbeda terhadap kemampuan dan keterampilan metakognitif, berpikir kritis, hasil belajar biologi siswa, serta retensinya di smp negeri manado. Disertasi tidak dipuplikasikan. Malang: PPs UM.

Wilson, C. (2001). Strategic and methods instruction. Needham Heights: Allyn and Bacon Publishers.

Wulandari, K. \& Muchlis. (2011). Meningkatkan hasil belajar siswa melalui pembelajaran aktif strategi group exchange pada IPA terpadu tema mata di kelas VIII SMP laboratorium Unesa. Makalah Seminar Nasional disampaikan di FMIPA UNESA pada Tanggal 10 Desember 2011. Surabaya: Unesa University Press.

Yuwono, M.S.C.

(2012). Pengembangan model pembelajaran kooperatif jigsaw modifikasi dari aronson dan slavin serta pengaruhnya 
terhadap keterampilan

metakognisi dan hasil belajar

biologi siswa berkemampuan

akademik berbeda di SMA Kota
DENPASAR. Disertasi, tidak diterbitkan. Malang: Program Pascasarjana

UM. 